\title{
Raising Healthy Children: Frugal Shopping Tips for Families ${ }^{1}$
}

\author{
Julie M. Martinez, Shari Bresin, and Karla P. Shelnutt ${ }^{2}$
}

In today's uncertain economic times, families are cutting their budgets wherever possible to make ends meet. This includes reducing the amount of money spent on food. Although a tighter food budget may make grocery shopping a challenge, learning how to stretch food dollars can help families afford enough healthy foods for the whole family to enjoy. This publication will discuss ways to plan ahead and strategies to help stretch your food dollars!

\section{Before Going to the Store}

Preparation is the key when it comes to saving money on food. It's smart to plan meals and to make a shopping list before going to the grocery store. This can help reduce forgotten food items, food waste, additional trips, unnecessary purchases, and missed discounts or sales. Follow the steps below to make the most of your shopping trip.

- Make a food budget. Calculate a food budget based on the USDA's low-cost food plan. An easy-to-use calculator is offered by Iowa State University Extension Service at www.extension.iastate.edu/foodsavings/fooddollar/.

- Check to see what you have on hand. Checking your pantry, kitchen cabinets, and refrigerator or freezer can reduce the chance of buying foods you don't need.

- Check store ads for sales. Plan meals for the week that include sale item ingredients.

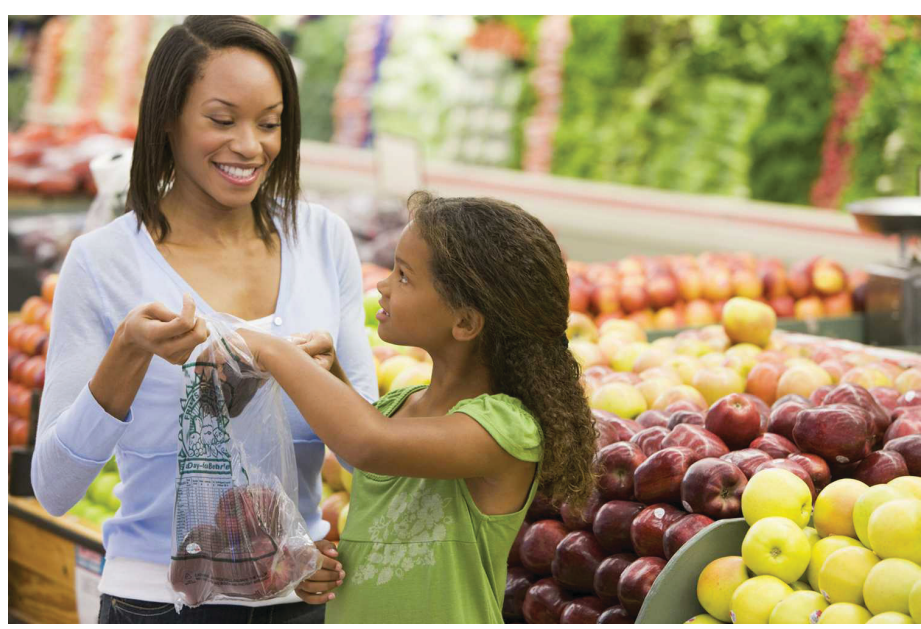

Figure 1.

Credits: iStockphoto

- Clip coupons only for foods on your grocery list. If you have children, ask them to help you with this.

- Plan meals and snacks for the week ahead. Remember to select foods high in nutrients and low in fat and sugar.

- Don't shop when you are hungry, tired, or angry. You are more likely to make impulsive purchases (Savoie Roskos \& Spielmaker, 2018).

- Make a list. Keep an ongoing grocery list that family members can add to when an ingredient or food item is running low or gone. Take the list with you when you go shopping to avoid having to make another trip.

1. This document is FCS8924, one of a series of the Department of Family, Youth and Community Sciences, UF/IFAS Extension. Original publication date April 2010. Revised December 2020. Visit the EDIS website at https://edis.ifas.ufl.edu for the currently supported version of this publication.

2. Julie M. Martinez, former dietetic intern, Master of Science Dietetic Internship Program, Food Science and Human Nutrition Department; Shari Bresin, Extension agent, family and consumer sciences, UF/IFAS Extension Pasco County; and Karla P. Shelnutt, associate professor, Department of Family, Youth and Community Sciences; UF/IFAS Extension, Gainesville, FL 32611.

The Institute of Food and Agricultural Sciences (IFAS) is an Equal Opportunity Institution authorized to provide research, educational information and other services

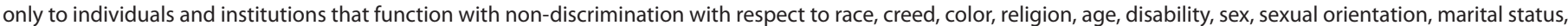

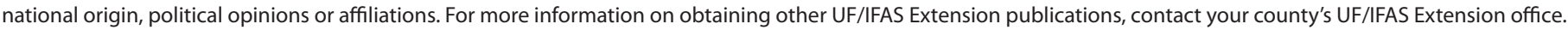
U.S. Department of Agriculture, UF/IFAS Extension Service, University of Florida, IFAS, Florida A \& M University Cooperative Extension Program, and Boards of County Commissioners Cooperating. Nick T. Place, dean for UF/IFAS Extension. 
- Consider meals that stretch. As you look over store ads to create your list, remember to make "bulk" meals once or twice a week. Liquid-based meals are the easiest to bulk up, such as chili, soups, and stews, and are likely to yield enough food to ensure leftovers for another night.

- Vary your protein. Animal-based proteins are usually more expensive than plant-based proteins. Go meatless a few nights a week and cook with plant-based proteins, like beans or lentils, to save money. You can also try canned meats, which are cheaper than fresh and frozen meats.

- Get enough fiber in each meal. Fiber makes you feel full, making it less likely you will want additional servings and leaving more food for leftover lunches or dinners. High-fiber meals include fruits, vegetables, whole grains, legumes, nuts, and seeds.

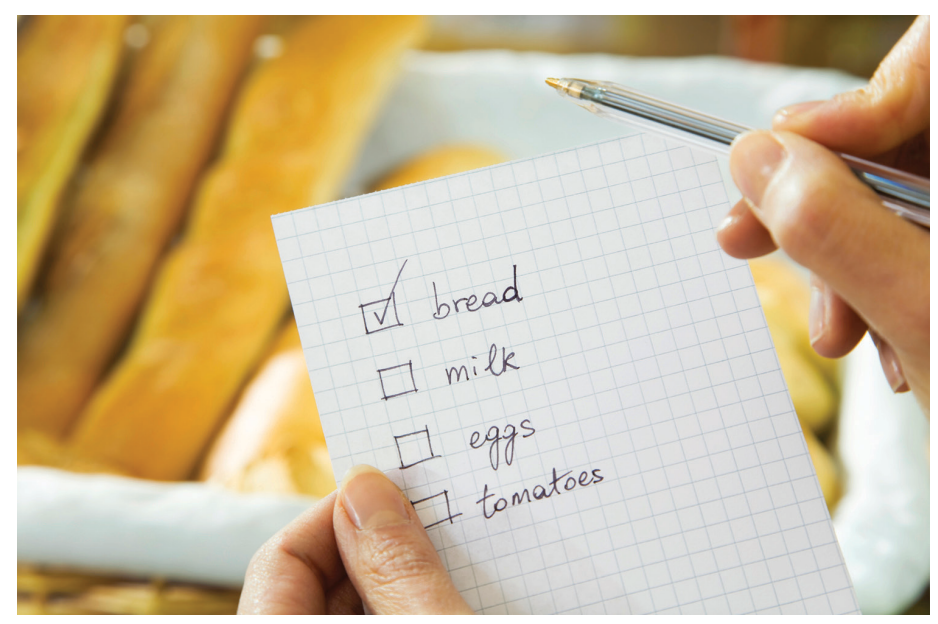

Figure 2.

Credits: iStockphoto

\section{Shopping at the Store}

The following strategies can be used to help save time and money at the grocery store.

- Try store brands. Store brands may be less expensive than brand-name items and can be just as nutritious and enjoyable (Soberman \& Parker, 2006). In some cases, they are made with the same ingredients or are manufactured on the same production line as the brand name (Green, 2014). Brand-name items are placed at eye level, so be sure to look on the upper and lower shelves for less expensive options.

- Check the "unit price" to compare similar foods. This tells you the cost per pound, ounce, or pint so you will know which brand or size is a better buy based on value. The unit price is usually placed right below the product on a shelf sticker (Figure 3).

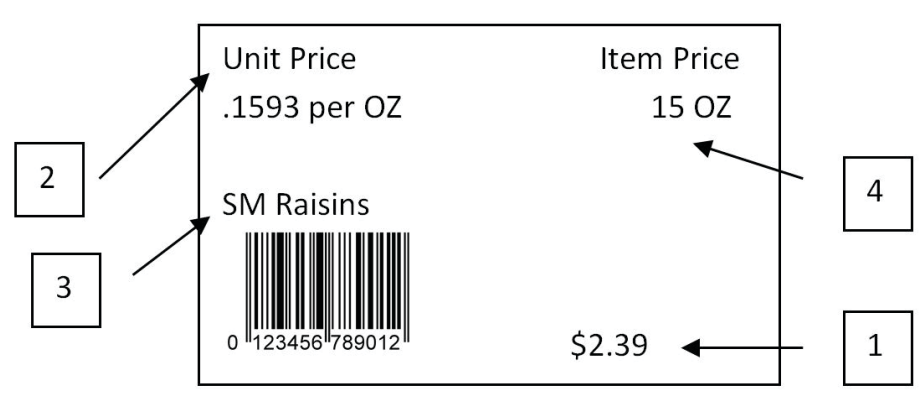

Figure 3. 1 . Retail price $=$ The price you pay; 2 . Unit price $=$ Price per unit-amount (ounces, pounds, pints); 3. Name of the food item; 4. Entire package size.

- Buy larger containers. They are usually cheaper. Make sure that your family will consume it while it is at peak quality.

- Read the labels and get the most for your money. Select foods with lower amounts of fat and sugar.

- Sign up for a bonus or discount card that your store offers for additional savings. Some grocery store discount programs include discounts on grocery, beauty care, health, and fresh items.

\section{- Buy fruits and vegetables in season.}

- Shop at your local farmers' market to find fresh, local produce at a good price.

- Purchase fruits and vegetables that are canned (in water or $100 \%$ fruit juice) or frozen. These have a longer shelf life! You can use frozen fruit in desserts or blend them into delicious smoothies by adding low-fat milk or yogurt. Canned or frozen fruits and vegetables are also good and affordable options when you want produce that is not in season.

- Avoid the junk food aisles when shopping. Skipping these aisles will make it easier to avoid temptation. Many prepackaged baked goods are high in fat or sugar and are costly to your wallet as well as your waistline. The perimeter of the store typically has the fresher food, while the internal aisles have the processed and prepackaged food.

- Buy milk (fat-free or low-fat) in larger containers. It is usually less expensive than purchasing it in quart containers. The least expensive milk option is usually non-fat dry milk. Milk from convenience stores is usually the most costly.

- Buy "whole" items and cut them into pieces at home to save money. Foods such as meats and produce are usually more expensive pre-cut. For example, buying poultry already cut into pieces is usually more expensive than buying the whole thing and cutting it at home. This is true for cut vegetables and fruits, too. 
- Stock up on sale items. Be sure to purchase only what you will eat if it is a perishable food. Stocking up can be especially useful for staple items that have a longer shelf life. For example, buy in bulk when you see buy-one-getone-free sales on perishable foods that can be frozen. Be careful not to stock up on unhealthy options just because they are on sale!

\section{Ways to Save at Home}

Use the following ideas to minimize waste and to help save money.

- Use batch-cooking. Cook a large amount of food, divide it into family-size portions, and freeze them for meals later in the month.

- Make your own healthy snacks at home and put them in small plastic bags or reusable containers. Mixing whole-grain cereals with nuts and seeds makes a quick, easy, and nutritious snack. Other options include cut fruits or vegetables, or whole-grain crackers with low-fat cheese. This can be healthier and more cost-effective than buying prepackaged and processed snacks.

- Freeze or refrigerate leftover foods or ingredients to use later. Leftover vegetables, meat, rice, and noodles can be used in other dishes such as stews or soups, or as toppings on a pizza or casserole.

- Understand food product dating phrases. "Best if Used By/Before" or "Use-By Date" is about quality, not safety (unless it's infant formula). The item may not need to be discarded.

- Organize your cupboard and refrigerator. Bring the older items and/or ingredients to the front and place the new items in the back.

- Grow your own vegetables and herbs. A small family greenhouse or garden is a great way to enjoy fresh vegetables. If you don't have time or room for a garden, consider growing small vegetable plants and herbs in indoor pots (see https://gardeningsolutions.ifas.ufl. edu/plants/edibles/vegetables/growing-vegetables-incontainers.html or https://gardeningsolutions.ifas.ufl.edu/ plants/edibles/vegetables/herbs.html to learn more).

- Save money by eating at home rather than at restaurants.

- Plan, organize, and be prepared to shop in a smart and frugal manner. This can help families maintain a healthy diet and manage their time while watching their wallets.

- Use apps and websites for rebates, coupons, and checkout codes.
- Install the FoodKeeper mobile app or check out their website: https://www.fmi.org/industry-topics/corporatesocial-responsibility/food-keeper-food-storage-database. This will let you know how long food lasts so you can consume it while it is still fresh.

- For more information on food storage at home, visit http://edis.ifas.ufl.edu/topic_food_storage.

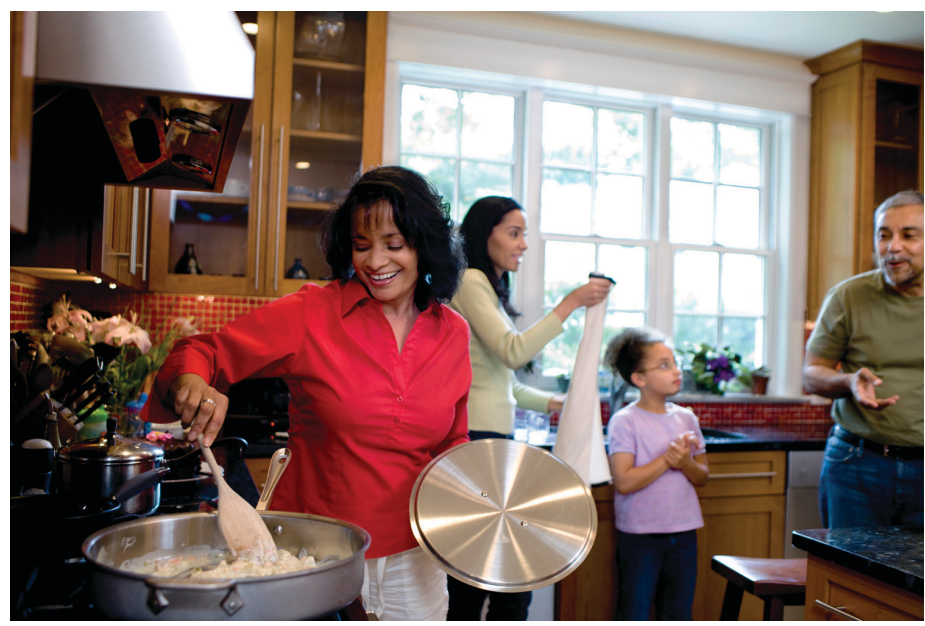

Figure 4.

Credits: Lifesize

\section{Learn More}

If you would like more information on frugal shopping, contact the following resources in your county.

- UF/IFAS Extension Family and Consumer Sciences (FCS) educator-UF/IFAS Extension offices are listed online at https://sfyl.ifas.ufl.edu/find-your-local-office/.

- A WIC nutritionist at your county health department.

- For referral to a registered dietitian nutritionist (RDN), contact the Florida Dietetic Association at (850) 3868850. Find an RD anywhere in the nation on https://www. eatright.org/find-an-expert. Look at the top right corner of the page.

\section{Recommended Websites}

Utah State University Extension: Freezer Meal Planning: https://digitalcommons.usu.edu/cgi/viewcontent.cgi?referer $=\&$ httpsredir $=1 \&$ article $=1303 \&$ context $=$ extension_curall

Fruitsandveggies.org: What Fruits and Vegetables Are in Season?: https://fruitsandveggies.org/stories/ what-fruits-and-vegetables-are-in-season/

Fresh From Florida: https://www.followfreshfromflorida. $\mathrm{com} /$

Choose MyPlate: Make a Grocery List: https://www. choosemyplate.gov/eathealthy/budget/budget-grocery-list 
Iowa State University Shopping Tools: Make a Master

Grocery List: https://spendsmart.extension.iastate.edu/

plan/shopping-tools/

Iowa State University Extension: Spend Smart. Eat Smart

Recipes: https://spendsmart.extension.iastate.edu/

Choose MyPlate: MyPlate Kitchen: https://www.choos-

emyplate.gov/myplatekitchen/recipes

\section{References}

Green, D. (2014). Food Riddle: When is a ge-

neric food not a generic? Retrieved from https://

livesmartohio.osu.edu/food/green-308osu-edu/

food-riddle-when-is-a-generic-food-not-a-generic/

Savoie Roskos, M., \& Spielmaker, A. (2018).

General Grocery Shopping Tips. Retrieved from

https://docs.google.com/document/d/1fWQR__zD-

JEEpkOgfcQ0eHKFxxY9r7oUE0-Q3j7G1Ik8/

edit?pli=1

Soberman, D. A., \& Parker P. M. (2006). The Economics of

Quality-Equivalent Store Brands. International Journal of

Research in Marketing, 23(2), 125-139. 